\section{The Muses and}

\section{Reflexive Nature}

\section{of the World}

in Archaic Greek

Thought

\section{ELIŠKA FULINNOVÁ}

Center for Theoretical Study

Charles University - Czech Academy of Sciences

Husova 4

11000 Prague 1

Czech Republic

Department of Philosophy and History of Science Charles University, Faculty of Science

Viničná 7

12844 Prague 2

Czech Republic

fulinova@cts.cuni.cz

\section{ABSTRACT}

In Greek mythology, the Muses are not just inspiring agents of poetical creation, but their role is first of all a cosmological one: their birth crowns the process of cosmogony, bringing the world into the manifestation. As we try to demonstrate primarily in the course of Hesiod's Theogony, the song of the Muses celebrates and thus manifests the cosmos or the world-order through its articulation by means of the musical speech. As the world enters a new domain of appearance, new cosmological categories emerge. The first one being the beauty of the cosmos: as a world-order as well as the ordered whole, it can now manifest itself as beautiful. The second one being the possibility of fiction, of a delusive appearance: the complex reality can manifest itself in many incompatible ways, partial and thus potentially misleading. The third one being the reflexivity of the cosmos, founded on the reflexivity of the musical speech itself. The Muses are capable to manifest themselves, and even their own manifestation. By means of their song, the world becomes manifest to itself, too, and the complex system of divine powers gains a reflexive character. In the closing section, we sketch briefly what happens to this reflexivity in the domain of humans. Indeed, the mortals can gain immortality through the song of the Muses, expressed by inspired poets in human voice."

This study is a slightly reworked and abridged version of a Czech article of the same author (orcid.org/0000-0001-9147-1796), Luhanová 2014. 
The general image of the Muses tends to include some awareness of the role these goddesses play in inspiring the works of literature, especially poetry. The notion of a special divine power dedicated to this task is specific to Greek myths: no parallels are found in the pantheons of other nations. The ancient Greek concept of a Muse or Muses is, however, much broader, and their most important function is not to contribute to human artistic endeavours but to fulfil a certain cosmological task. This aspect of Muses was studied in detail by Walter F. Otto,${ }^{1}$ and Sylva Fischerová, a leading

1 Otto 1955. Of importance in this context are also some smaller works from the 1950s that treat the subject of Muses in a more general context of mythic manifestation and selfrevelation of being, especially Der Mythos und das Wort (1952-1953), Der Mythos
Czech Classical scholar, follows in his footsteps when she claims:

The idea that musical and poetic talents are divine, and art is used by gods is part of at least the Indo-European heritage. Only in Greece, however, do we find a Muse who not only brings divine art and gives it to people, but also reveals and declares that she herself and her work is part of the order of the world, that it is part of its way of being. ${ }^{2}$

Through a musical word, that which is can reveal itself and relate to itself in its manifestation. And more specifically,

(1955), Die Sprache als Mythos (1958), collated in Otto 1987.

2 Fischerová 2006a, p. 63. 
archaic thoughts expressed in the works of inspired poets can, thanks to this divine gift, relate to themselves, express themselves in speech, and apprehend themselves in a particular manner. Thanks to the Muses, there thus arises the primary ground of cosmic reflexivity that makes self-relating and self-understanding possible. In the following study, we trace the cosmological aspect of this phenomenon. In doing so, we rely especially on the treatment of this subject presented by Hesiod in his Theogony.

\section{THE WORLD MANIFESTS}

\section{ITSELF IN A MUSICAL SPEECH}

We can take as our starting point the story of the birth of the Muses, a point which W.F. Otto believes to be the key to a better understanding of the Muses and their role in the world of ancient Greece. The story of their birth is attributed to Pindar and its shortened version appears in the writings of Aelius Aristides:

Pindar went so far that he says that in the marriage of Zeus, upon Zeus asking the gods if they desired anything, they requested that he create for himself gods who would honour ( $\kappa \alpha \tau \alpha \kappa \circ \sigma \mu \eta \dot{\gamma} \sigma 0 v \sigma \mathrm{l})$ in words and music these great deeds and all of his preparations. ${ }^{3}$

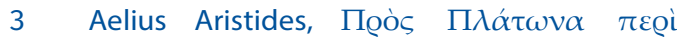

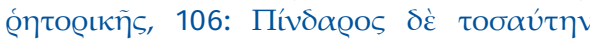

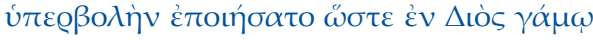

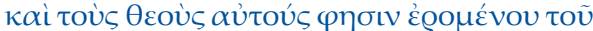

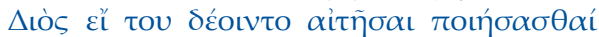

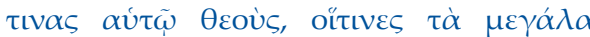

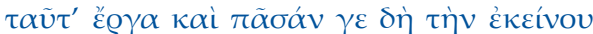

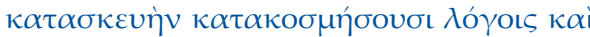

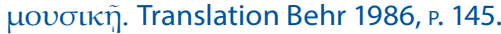

A similar 'ancient story' ( $\pi \alpha \lambda \alpha$ ı̀̀ $\lambda o ́ \gamma 0 \varsigma, \tau \tilde{\omega} v \pi \alpha \lambda \alpha \mathrm{L} \tilde{\omega} \nu \mu \tilde{v} \theta \mathrm{o} \varsigma)$ is also recounted by Philo of Alexandria. ${ }^{4}$ In his version, the creator of the world, after finishing the whole cosmos (ó $\sigma u ́ \mu \tau \alpha \varsigma$

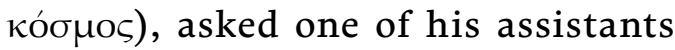
whether there was something missing among the things arisen. The assistant then replied:

... that everything was perfect and fully completed, but that there was just one thing missing, namely a word praising it, which should not so much

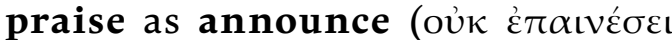
$\mu \tilde{\alpha} \lambda \lambda$ ov $\hat{\eta} \hat{\varepsilon} \xi \alpha \gamma \gamma \varepsilon \lambda \varepsilon \tilde{\imath})$ the pervasive excellence ... because the narrations of god's deeds represent their fully sufficient praise, since they do not need any external addition as an embellishment ( $\delta \varepsilon 0 \mu \varepsilon ́ v \omega v) .^{5}$

Zeus liked this idea, which is why he begat with Mnemosyne, embodied Memory, a generation of Muses, goddesses who celebrate and thereby complete the whole of the ordered world.

Where Pindar according to Aelius says that what the finished world needs for its completion is to be honoured, Philo emphasises that it is not about

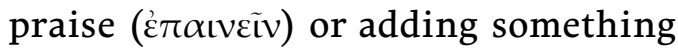
to what there already is. What the world needs to be complete is an account, or

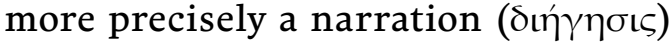
that would announce ( $\dot{\xi} \xi \alpha \gamma \gamma \varepsilon \dot{\varepsilon} \lambda \varepsilon เ v)$, that is, express and tell in words, the divine

Philo Judaeus, De plantatione, 127-130. Philo Judaeus, De plantatione, 127-128. 
deeds and order of the world as it already is. Philo points out that divine actions do not require that anything be added: as soon as they are spoken, spelled out, they are their own tribute and praise. The world thus not only exists but thanks to a musical speech also manifests itself, whereby musical speech does not add anything to reality. It just makes reality explicit, expressed, and apparent in what it is, even in its dynamic aspect, that is, in capturing the events thanks to which reality acquired its definitiveness. Manifestation thus conceived therefore becomes, through the Muses, the way of being of the world and the song of the Muses is a cosmogonic act because it represents a constitutive culmination of a process it celebrates.

\section{A BEAUTIFUL WORLD IN BEAUTIFUL, BUT POSSIBLY DECEPTIVE WORDS}

Hymn is an ancient literary genre that celebrates and 'praises' divine realities and claims to have its origin in the Muses. ${ }^{6}$ Longer hymns articulate their content in two interconnected parts: descriptio, which captures the typical qualities, attributes, and sphere of agency of the god it celebrates, and naratio, the core of the story of the hymn, which explains a particular aspect of the god described

See a collection of Homeric Hymns where 'celebration' is usually expressed by the terms $\alpha \varepsilon \varepsilon^{\prime} \delta \varepsilon \iota v$ or $u \mu \nu \varepsilon \tilde{v} v$. This collection contains both some more extensive hymns, which follow the structure described below, and shorter hymns, akin rather to an invocation of a deity to which a poem is dedicated and whose celebrated actions are briefly summarised in a few verses. above. ${ }^{7}$ Naratio achieves this either by telling a story from the life of the divine power celebrated by the hymn, a story that captures the god's nature, or by applying a diachronic genealogical perspective, that is, by telling how the god was born and eventually found his or her place in the divine order. A hymn thus expresses the reality it celebrates in two distinct ways: by describing its essential nature and by recounting the process that led to its establishment.

Hesiod's Theogony represents a culmination of the hymnic form thus defined. The monumental construction of this work is unique, but its basic structure is analogical to some other longer hymns preserved as part of the Homeric

The distinction between descriptio and naratio was proposed in the context of analysing the structure of hymns in Miller 1986. Similarly, Richard Janko draws a distinction between a 'myth', i.e. a story told in the past tense, and 'attributes' in the sense of a description of properties of a divine being, recounted in the present tense; see Janko 1981. This duality is also noted in the Chadwicks' monumental overview of the history of literature; Chadwick - Chadwick 1940, p. 785. The Chadwicks note that the Greek hymnic form blends a timeless description of the kind that was in archaic world literatures usually associated with a celebration of divinity and is seen as a sign of a poem's sacred status, with a diachronic narration of stories that tends to be a form used in secular poetry, especially heroic epics.

The traditional philological approach tends to distinguish between 1. invocatio, an invocation of a divinity that includes the use of its name, epithets, etc., 2. pars epica, which elucidates the nature of the powers of the god addressed by the poet, and finally 3. preces, a concluding formulation of a wish whose fulfilment the poet asks for. This structure is found in both the short and the more extensive compositions in the Homeric Hymns. See e.g. Versnel 1981, p. 2. 
tradition. The Theogony as a whole is a hymnic praise of Zeus's world order that takes the form of description of the cosmogonic process which led to the establishment of the world in its current form. The introduction, or prooimion, ${ }^{8}$ is designed as an independent hymn to the Muses. ${ }^{9}$ Musical speech, which Hesiod, as poet, relates, and which expresses a mythical story about the origin of the cosmos, not only recounts this story but also becomes its final act of completion. Through the Muses, reality assumes the shape of a word that can be uttered by a human mouth. Poets inspired by the Muses are thus not impartial, disengaged, external observers and reporters. On the contrary, poets, in virtue of their actions, by interpreting a musical word through the medium of human speech, become part of the order of the world and help complete its constitution. Poetic speech thus makes the subject of its depiction immediately present.

As soon as the world manifests itself through expression in a musical speech, an important new aspect comes into play, namely the beauty of the world that thus appears. Hesiod in his prooimion emphasises the beauty of the Muses and all their works, especially their 'splendid

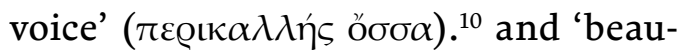

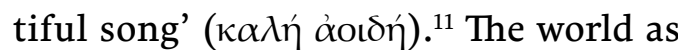
a whole, meanwhile, was already in the Archaic Period referred to by the term

\footnotetext{
8 Hesiodus, Theogonia, 1-115.

9 Cf. also Fischerová 2006b.

10 Hesiodus, Theogonia, 10.

11 Hesiodus, Theogonia, 22
}

cosmos,${ }^{12}$ which indicates that it is both organising and organised. A cosmos is not only the sum of all there is, but also the order that makes it a meaningful whole. ${ }^{13}$ The whole of what there is is then not only properly ordered but also beautiful. ${ }^{14}$ The semantic roots of the expression cosmos, which reach all the way to Homer, reveal that the term combines a meaning of a purposeful order ${ }^{15}$ with the meaning of a neat arrangement, ornament, or embellishment. ${ }^{16}$ The idea of beauty achieved by ordering, that is, by the creation of a properly ordered and organised whole where everything is in harmony with its surroundings and its context, is characteristic of Greek

12 It is commonly assumed that the first to use the term cosmos to denote the whole of the universe was Pythagoras in the 6th century BCE (DK 14 A 21).

13 For more on the history and meaning of the term cosmos, see Kahn 1994, pp. 219-231.

14 Various pieces of evidence pointing to this aesthetic or 'cosmetic' use of the term cosmos are brought together by Šedina 1997, pp. 11-15. Cf. also Šedina 1995.

15 Often, though not exclusively, in connection with arraying the army, i.e. placing it in battle order, or in connection with adjusting

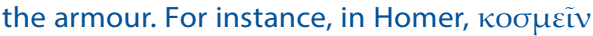
can refer to putting on one's armour (Ilias, II, 873), to arraying or marshalling the troops (Ilias, II, 474-476; III, 2-7), or even to pitching a camp (Ilias, VII, 52). Similarly, the ex-

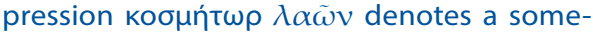
one who organises an army (Ilias, XVI, 375; Odyssea, XVIII, 152). This notion of proper arrangement can, however, also apply to food (Odyssea, VII, 13) or even to well-kept vegetable beds (Odyssea, VII, 127).

16 Hera, when preparing to entrap Zeus, is decorating herself, whereby her toilette is de-

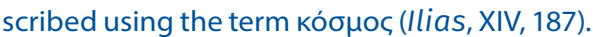
Even a nice bridle is an 'ornament', kó $\sigma \mu \circ$, for

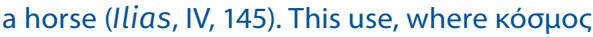
denotes an ornament or a jewel, became quite common in Classical Greek. 
thought as a whole. In order for the world to be apprehended as essentially beautiful, meanwhile, it must reveal or manifest itself: after all, 'beauty, if indeed it is beauty, must be manifest'. ${ }^{17}$

Both versions of the abovementioned 'ancient story' play on the duality of ordering and beauty inherent in the concept of cosmos. ${ }^{18}$ According to Aelius, the Muses are supposed to 'honor' the world, whereby the term $\kappa \alpha \tau \alpha \kappa о \sigma \mu \varepsilon ́ \omega$ refers not only to beautification but also, more commonly, to ordering, thus hinting on the cosmogenic process completed by actions of the Muses. In Philo's version, the Muses arrive at a point where the

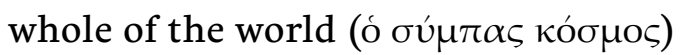
is finished. This cosmos needs no addition of external things 'as an em-

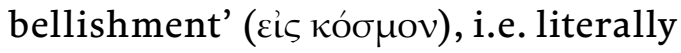
'to become cosmos'. It only needs to be uttered, spelled out, to properly reveal itself in all of its beauty, in its cosmic nature. In the Archaic world, beauty is thus not an aesthetic addition. It is a cosmological category: appearing beautiful is the world's way of being, whereby the voice in which the divine cosmos speaks of its beautiful being are the Muses. Their speech is thus truly 'cosmic' and it is no coincidence that in ancient times, one of the terms for

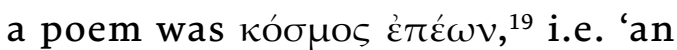

17 Fischerová 2006a, p. 63.

18 Cf. also Kahn 1994, p. 220.

19 Democritus speaks in this way about Homer's work (DK 68 B 21), while Parmenides uses this expression (with the adjective $\alpha \pi \alpha \tau \eta \lambda$ ós, 'deceptive') to present a cosmology that was explained to him by a Goddess after she disclosed the truth to him. Solon uses the term ordered whole of verses' or 'ornament made of poetic words'. In this way, the cosmos of poetic words and cosmos of reality revealed in them share the same essence. $^{20}$

The manifestation of reality in the medium of speech does, however, bring along yet another new element, namely the possibility of deception. Manifestation brings into the whole of reality a plurality of perspectives: that which is can appear in various ways and in some contexts, it can seem different from the way it is. Fictitious appearance thus becomes one of the ways of being of reality. That is also what the Muses say about themselves in the prooimion to the Theogony when they admit that their song can be both truthful and deceptive:

...we can make falsities and fallacies seem true, but when we want we're able to give truthful statements, too. ${ }^{21}$

This statement captures a factor that is of key importance in understanding the nature of a poetic depiction of the world. Nevertheless, the speech by which the goddesses characterise their own words is quite peculiar due

to denote his own poem (West 1992, fr. 1, 2),

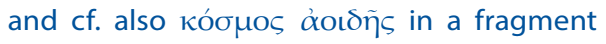
ascribed to Orpheus (DK $1 \mathrm{~B} 1$ ).

20 Fischerová 2006b, p. 360.

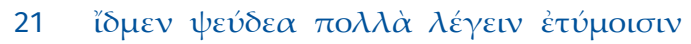

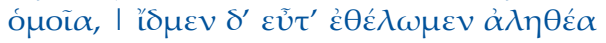

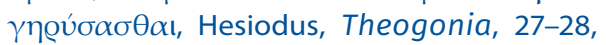
translation Caldwell 2015. The key term here are the pseudea; this expression can be used to denote anything that is not in agreement with reality, i.e. both a deliberate lie and an error or a made-up nonsense. 
to its self-referential form. ${ }^{22}$ That is, when they admit to being skilled liars, we are forced to ask ourselves whether the Muses decided to reveal their true nature, or they are just trying to mislead us. ${ }^{23}$ Can we and should we trust their worlds? In fact, the Muses' declaration that they can deceive cannot turn out to be false because if, in using it, the goddesses really wanted to mislead us, they would only confirm the truth of their claim. However, the speech of the Muses is not just a logical puzzle. After all, the purpose of it is above all to spell out the reality of the world! Let us therefore try and interpret their statement and its specific form within this cosmological framework. ${ }^{24}$

Cf. the amazing career of words which the Cretan thinker Epimenides allegedly said when angry with his fellow islanders, namely that 'all Cretans are liars' (the statement is quoted in the New Testament, Titus 1:12, and ascribed to Epimenides by Clemens Alexandrinus, Stromateis, I, 14). Possibly the first to realise the paradoxical nature of such self-referring statements was Eubulides of Miletus in the 4th century BCE. It was he who included in his list of seven logical paradoxes also the Liar Paradox, which states 'What I am saying now is false'; see Diogenes Laertius, Vitae philosophorum, II, 108.

23 In contrast to deception, the goddess's professed ability to sing properly about reality did not give rise to doubts in ancient times. On the contrary, it may have been seen as an integral part of abilities of goddesses who see all there is and all there has been (Ilias, II, 485, cf. also Odyssea, VIII, 491) and in virtue of their being the daughters of Mnemosyne, the goddess of memory (Hesiodus, Theogonia, $54,915)$, which made them the chief power confronting forgetting.

24 This passage became the subject of many different interpretations. For a brief, yet useful overview, see Clay 1988, pp. 327ff.; for a more thorough overview, see Scodel 2001, pp. 115ff. The paradoxical form of the Muses' statement
It seems now that in a world that is and appears through speech, the possibility of existence of non-truth is very truthful. In other words, things can appear different from the way they are, and this potential is inherent in the way they exist. The possibility of appearance of things that are not is thus part of reality of a world whose being is completed by its appearance in a musical speech. Deception turns out to be the means of an appropriate expression of reality, because even speech that communicates deceptive content on a lower level adequately discloses truth about the being of this world. In this way, fiction that resembles reality is not just an imperfect imitation of truth but rather a consequence of elevating reality to a poetic state, a way of referring to its appearance in musical speech.

Truthful and truthlike musical speech can thus express not only what there really is but also what might be true. This truthlikeness, which can cause us to mistakenly think that possibility is reality or that a partial perspective represents the whole, is what underlies the enchanting, enthralling quality of musical speech and its ability to deceive the addressee. Deceit in general is an integral part of the cosmogonic process. It is both a consequence and a further cause of conflicts that take place between divine powers,

is treated by Pucci 1977, however he draws consequences for the nature of the logos only. We are not aware of any interpretation that pays attention to the self-referential nature of the statement and tries to apply it in the context of the reflexive being of reality that manifests itself. 
conflicts which play a constitutive role in cosmogony. Be it the ruse prepared by Gaia (the Earth) thanks to which Ouranos (the Heaven) losses its position in favour of Kronos, ${ }^{25}$ the trick which Rhea, with the help of Gaia, uses to deceive Kronos and open the way to Zeus, ${ }^{26}$ or the compliments Zeus uses to outwit Metis and to prevent the birth of an offspring who would replace him as the ruler of the world ${ }^{27}$ - all these are key turning points of cosmogony. And although these tricks gradually assume an ever more sophisticated form (we witness a gradual shift from a violent action executed by a sharp blade to deliberate use of coaxing and persuasion), the deceit has in all cases an analogical structure. The subject who is being tricked does not properly understand what is happening and what is at stake: without being aware of it, he or she views things only from his or her own narrow perspective. The subject of deceit is unaware of some crucial factors which set the current reality into a wider context whose meaning is determined not only by past events, but also, and more importantly, by certain undisclosed plans and intentions of the deceiver. This structure can be applied to interpreting the meaning of Muses' declared ability to deceive. In particular, what is deceptive is any partial perspective that is unaware of its partiality, and any speech that mediates a partial perspective is likewise

\footnotetext{
25 Hesiodus, Theogonia, $160 \mathrm{ff}$.

26 Hesiodus, Theogonia, 485ff.

27 Hesiodus, Theogonia, 886-900.
}

deceptive. This implies that because the Muses do not promise to tell the truth and nothing but the truth, they can mediate various partial ways of understanding reality, and thereby capture even conflict and strife.

It seems that a fitting way of capturing reality in its plurality, multiple layers, and incompatibility of various ways of revealing itself is this polyphony of the truthlike. A multiplicity of voices that expresses reality in its totality by apprehending the various partial perspectives revealed by their mutual conflict as partial, would in fact be a true speech. Listeners would be deceived only if they did not see through the limitations of each partial perspective, only if they thought it was the whole truth. ${ }^{28}$ Musical speech, potentially always deceptive, thus seems more appropriate in comparison to a speech that could never lie because it reveals a deep truth about the conflicted nature of reality differentiated between being and appearing.

The insight that each and every limited, partial perspective is deceptive is a typical subject of Classical tragedy, since in a tragic conflict 'truth' is not in possession of either of the opposing parties. The nature of reality reveals itself more adequately in the potentially conflicting yet justifiable claims that stem from it. This is evident, for instance, in the quandary faced by Orestes in Aeschylus's Oresteia, a conflict rooted in incompatible claims rooted in the relation to a father and a relation to a mother. Already in the Archaic Period, however, this motif is also at the core of Homeric conflicts between gods, while in Hesiod's writings, it is expressed for instance in the argument between Zeus and Prometheus regarding proper treatment of mortals; see Hesiodus, Theogonia, 532-616, Opera et dies, 42-105. For more on the context, see also Aeschylus, Prometheus vinctus and Vandvik 1943. 
From this perspective, a musical composition perceived as a revelation of the being of the world in one of the facets of its appearance - and therefore also the cosmological explanation provided by Hesiod - seems utterly true in the sense of adequately capturing the being of a thus understood reality. ${ }^{29}$

\section{REFLEXIVITY OF MUSICAL SPEECH AND OF THE WORLD IT REVEALS}

From all of the above, it follows that musical speech is essentially reflexive. This speech reveals not only the reality it expresses, but through its ability to relate to itself, it can also disclose the nature of this appearance, a plurality of possibilities of appearing that is a way of being of reality, a plurality that completes the way the world is. A musical word is thus transparent to itself: together with what is being revealed, it manifests also itself, the sphere of manifestation as such. ${ }^{30}$ This reflexivity is now present

Cf. also Plato's statement (in Plato, Respublica, 382a ff.) according to which everything a god says must be true. This explicit claim, however, is influenced by a shift in the meaning of 'truthfulness' that took place between the Archaic thought and Classical philosophy. This meaning shift also probably corresponds to a deep change in the understanding of reality, so that while a Platonic god cannot but express truth, Archaic Muses proudly declare that they use potentially deceptive speech, because it adequately describes a reality that is inherently full of conflict and contradiction.

This interpretation of the Muses is defended by Walter F. Otto, especially in his study Der Mythos und das Wort (see note 2). He views their reflexive nature as a characteristic feature of Greek myth that has to rely on musical speech. In the speech of the Muses, truth appears in such a way that the person to whom it is revealed is aware not only of the reality thus on both levels that correspond to the two main hymnic parts of the Theogony: first as the Muses' self-relation, and then as a self-relation of the totality of the world, which in the medium of a musical word becomes apparent to itself.

We have already seen that the speech of the Muses can relate directly to itself. In Hesiod's hymn to the Muses, however, the goddesses do not reflect only on the nature of their speech. Instead, through the voice of the poet they also present a brief outline of its content and on top of that, they describe their own birth, nature, and purview of their divine actions. ${ }^{31}$ This corresponds to the task the Muses gave the poet during his initiation: in addition to praising the family of gods and singing about the past and the future, they also demanded that at the beginning and the end, he ought to praise them. ${ }^{32}$ Such a request also constitutes

disclosed but also of the fact that it appears. In other words, reality appears in its truth as appearing.

31 Form-wise, the speech of the Muses is presented in poems in three different ways: Firstly, and most commonly, directly, that is, when a poet speaks of deities in a third person (while sometimes enlivening the story by inserting direct speech); in this way, the poet usually speaks about the Muses. Secondly, and less commonly, Muses appear in an indirect narrative, i.e. in a story about a story, when a poet summarises what the Muses say (e.g. Hesiodus, Theogonia, 45-49). And finally, we find some direct quotations of what the Muses say, that is, records of what the goddesses say about themselves in first person (Hesiodus, Theogonia, 25-27). This category may also include the cosmogonic narrative that forms the main content of the Theogony (Hesiodus, Theogonia, 116ff.), since it is possible that it is a direct quotation of the speech of the Muses.

32 Hesiodus, Theogonia, 34. 
an obligation on their part, namely that they shall disclose to the poet their own divine being. After all, how else would a mortal access it? Hesiod's poem meets this request, ${ }^{33}$ which implies that the Muses are both the source and addressees of the hymnic celebration. Hesiod's hymn should therefore be read also as a self-manifestation of the Muses in a musical speech as interpreted by human verses. This formal structure of a musical song indicates that the Muses can, in their own speech as interpreted by the poet, create a mirror that reflects them. After all, the goddesses want to hear praises sung to them, just like in the 'ancient story' recounted above, gods - who wanted the Muses to be born - wanted to hear themselves honoured.

A self-relating musical speech can also become a medium of self-relation for the reality it expresses, i.e. for the world order and individual divine powers that constitute it, and subsequently also for humans. Thanks to this duality of reflexive structure, musical speech is not just a 'mirror' of the world. It is also transparent to itself and ought to be accorded the same kind of being as the world it expresses, the world which finds in it its own completion. Likewise,

33 Hesiod starts his poem with the Muses (Theogonia, 1) and returns to them at the end, when cosmogony reaches a point when they are born (Theogonia, 915-917). The very end of the Theogony as it is available to us now thus forms a smooth transition to the following composition, the so-called Catalogue of Women, which is nowadays usually seen as a late addition. There is no agreement on the verse with which the Theogony actually ends: proposals range from verse 939 to 964 . For a detailed discussion of this subject, see West 1966, pp. 398-399; 48-49. the world order that is being celebrated figures not only as an object but also as the addressee of a musical song. The totality of the world is, after all, a complex network of divine powers, established by a genealogical process where individual gods function as its constitutive elements. ${ }^{34}$ When, at the end of organising and arranging the world, the gods wished to hear words that would properly celebrate this order and the divine deeds that established it, they requested a voice that would sing about them. The ultimate hymn that completes it all is then a cosmological song, which can capture them in their mutual relation, i.e. in their cosmicity.

Hesiod's hymn emphasises the reflexive duality especially in the case of Zeus, who is at the very centre of the cosmological paean. Zeus is the creator and guarantor of the world order, the father of people and gods, the best and mightiest of them

34 This not does exclude the possibility that some gods help establish the order in a so-to-say negative way, for instance by presenting themselves as threats that need to be either newly integrated or suppressed. An example of the latter are the Titans who did not find a fitting place in Zeus's order and were, together with Kronos, thrown into an underground prison; see Hesiodus, Theogonia, 729-733, 813-814). The former group, those who need to be reintegrated, includes mostly the old gods who in many cases form the basic spatial constituents of the world, but there is a degree of tension between them and the new Olympic order. For instance, the position of the Earth (Gaia), who sometimes helps Zeus as a prophetic force (Hesiodus, Theogonia, 891), while threatening him at other times with her immense generative force (as in the birth of Typhon, Theogonia, 820 ff.) is ambivalent in this manner. For more on this subject, see also Bonnafé 1984, p. 211. 
all, ${ }^{35}$ the god who after defeating Kronos stamped on the world its current form when he determined the rules by which cosmos exists and delegated to other gods their spheres of power. ${ }^{36}$ Hesiod's cosmological hymn reflects Zeus's privileged position also in virtue of being 'dedicated' to him in both senses of the word: Zeus's world order is the main subject of the musical celebration and Zeus is the main addressee of the hymn. The Muses are born at the end of the cosmogonic process, when Zeus consolidates his position by marrying goddesses of the old generation: the Muses are daughters of Zeus and Mnemosyne, a Titaness and embodiment of memory. ${ }^{37}$ While they are born in Pieria ${ }^{38}$ and often dance on the hill of Helicon, ${ }^{39}$ their main seat is on the Olympus, ${ }^{40}$ in the immediate vicinity of their father, in whom they originated and to whom they keep returning to please his mind. ${ }^{41}$ Just like the poet thus begins and ends his song with the Muses, so the song of the Muses has its beginning and end with Zeus.

The song of the Muses is not, however, limited to Zeus either in its content or by being addressed to him exclusively. The 'divine voice' 42 of the Muses reveals the rules or customs that

Hesiodus, THEOGONIA, 47-49.

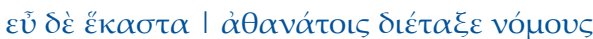

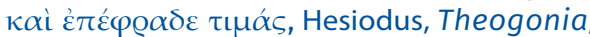
73-74.

37 Hesiodus, Theogonia, 53-54, 915-917.

38 Hesiodus, Theogonia, 53ff.

39 Hesiodus, Theogonia, $1 \mathrm{ff}$.

40 Hesiodus, Theogonia, 75.

41 Hesiodus, Theogonia, 36-37; 51-52; 75.

$42 \alpha \ddot{\mu} \mu$ @ootos ö $\sigma \alpha$, , Hesiodus, Theogonia, 43. regulate the universe and the nature of all divine powers who are in charge of upholding and maintaining them. ${ }^{43}$ The subject of their celebration is the whole family of immortal gods, ${ }^{44}$ that is, not only the actually ruling generation of Olympians ${ }^{45}$ but also the older powers, be it those whose suppression had confirmed Zeus as the supreme ruler (such as the Titans and giants) ${ }^{46}$ or the primordial gods who play the role of cosmogonic beginnings (the Earth, the Sky, the Night). ${ }^{47}$ In a diachronic genealogical narration, the Muses are 'telling of things that are, of things in future that shall be, and things that were before, out of their mouths in sweet, unwearying harmony the voice flows.... ${ }^{48}$ The song of the Muses is presented here as a cosmological prophetic statement ${ }^{49}$ that should be interpreted through the prism of a shared foundation of the musical composition and the whole of the world. The 'unwearying harmony' refers to the singing of the paean that is at the same time the final act of cosmogenesis. This completion,

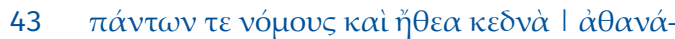
$\tau \omega \nu \kappa \lambda \varepsilon$ ćovoเv, Hesiodus, Theogonia, 66-67.

44 Hesiodus, Theogonia, 44.

45 Esp. Hesiodus, Theogonia, 11-15.

46 Hesiodus, Theogonia, 16-20; 50.

47 Hesiodus, Theogonia, 45-46; cf. also 20.

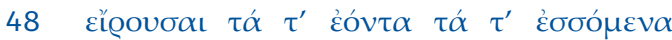

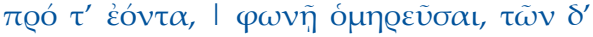

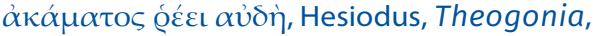
38-39, translation Caldwell 2015.

49 Cf. for instance Ilias, I, 70, where we find a similar formula describing the knowledge

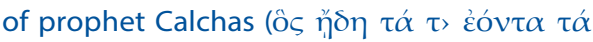

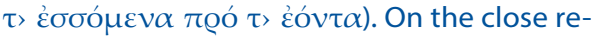
lation between prophets and poets, see also Dodds 1951, p. 217. 
culmination of creation, consists in the uttering and listening. In the tradition, there exists a topos where the song of the Muses is an integral part of the feasts of gods. Hesiod, too, paints a remarkable picture where the voice of the Muses fills the whole abode of the deathless, the mountain top of Olympus resounds with a song of praise that spreads around, ${ }^{50}$ and when the Muses move, even the black Earth, ancestor of all gods, hums along and reverberates in the rhythm of their song and dance. ${ }^{51}$ Gods view themselves in their long-desired mirror with pleasure: they listen to a voice in which their own being is completed by being disclosed to themselves. Cosmos, the world order created by gods and their relations, thus becomes capable of relating to itself.

\section{IN PLACE OF A CONCLUSION: MUSICAL SONGS IN THE SPHERE OF THE MORTALS}

Musical gifts are not altogether denied to mortals, either: not only gods, but even a chosen person on whom the Muses had bestowed the gift of interpreting divine song in human speech can hear the divine voice that reveals the being of reality. 'Give me an oracle, Muse, and I shall be your prophet', says Pindar ${ }^{52}$ when commenting on the transposition of divine voice into the medium of human speech. What happens now with

\footnotetext{
50 Hesiodus, Theogonia, 40-42.

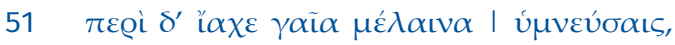

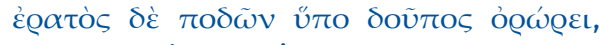
Hesiodus, Theogonia, 69-70.

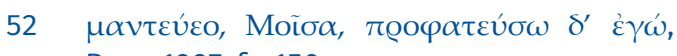
Race 1997, fr. 150.
}

the reflexivity of musical word, when a poet translates it into a form suitable for ears of mortals? Can human speech preserve the possibility of self-reflection that is an essential characteristic of a divine speech? Such questions would deserve a close study on their own. Let us just note that the possibility of self-relation is not lost in transposition into the level of human speech, but it does acquire some new dimensions.

Expression of the transient human existence in words of praise is above all one of the privileged ways in which a moral being can participate in the permanent being of the divine order. ${ }^{53}$

According to Hesiod, gods are beings

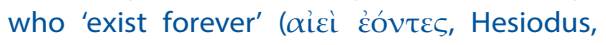
Theogonia, 105): they are born but they never pass away, thus escaping the otherwise inviolable symmetry of birth and death; this applies to the being of the world as a whole as well. The philosophical heir of this conception is Plato; see Plato, Timaeus, 41a ff. and Sedley 2010.

Monsters beings occupy a special position, since while divine, they can also be mortal (e.g. Gorgon Medusa, the Lernaen Hydra, the giant Geryon, and others, see esp. Hesiodus, Theogonia 270ff. and 295ff.). The monstrous character of these beings expresses their liminal position within the order. They embody a fading of the constitutive difference between the mortal and the deathless. Consolidation of the cosmic order therefore requires their liquidation, a task that usually falls to one or another of the heroes, whereby heroes, themselves products of mixed unions between gods and people, are similarly hybrid and liminal beings. Especially noteworthy example of this is Zeus's son Heracles, who as the 'long arm' of the highest of the gods ended up killing so many monsters that he was accepted into the Olympic pantheon (see Hesiodus, Theogonia, 950-955). A fateful meeting of a monster and a hero thus paradoxically reaffirms the distinction between the mortal and immortal, since while the monstrous divine being dies, an offspring of a god and a mortal woman receives his share in the fully divine deathless existence. 
A poem dedicated to a celebrated hero

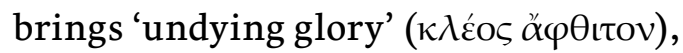
keeps him alive in collective memory and prevents his fall into the abyss of forgetting. In other words, to be celebrated in a poem is to gain immortality. ${ }^{54}$ We had already noted that Muses are the daughters of Mnemosyne, i.e. Memory. In this context, musical speech turns out to be a crucially important two-way link between the divine order and human world: the word of a poet reveals and reminds mortals of the divine order ${ }^{55}$ in order to help them lead their lives in fitting harmony with it. ${ }^{56}$ At the same time, it has the power of turning a human life into an unforgettable story, thus elevating it to a level of non-transitory, permanent being.

This significantly enhances the poet's status: after all, it is poets who turn human subjects of their stories into immortal heroes. This appearance in the medium of poetic speech constitutes a culmination of the constitution of human existence. Archaic people, whose individuality was constituted not internally but by the way they appeared

54 See Detienne 1979, p. 23. The understanding of speech as a medium through which immortality can be achieved is also shared by Plato (on poetry in particular, see e.g. Plato, Symposium, 209d).

55 Cf. for instance the introductory verse of the Hymn to Apollo, where instead of the common formula about the poet's desire to celebrate gods, we find something different, namely 'I will remember and I won't forget

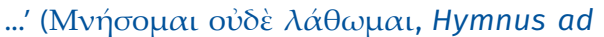
Apollinem, 1). A similar opening is found

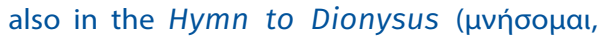
Hymnus ad Bacchum, 2).

56 An excellent example of this is Hesiodus, opera et Dies. on the outside, needed others to be fully constituted. They became who they were only in the image reflected in the eyes of others. ${ }^{57}$ Poets could express this personal appearance in a musical speech, and thus preserve it and spread it even after the mortal subject of a poem succumbed to death and the non-appearance of the underworld. And as long as a mortal lives on in the poem, so does the poet, too, who expressed the mortal's being and who is well aware of his exceptional status. 'So also you, O Polycrates, will have a glory of song that is unwilting, as in line with the song and with my own glory of song,' says Ibycos to the tyrant Polycrates, whom he praises. ${ }^{58}$ In Hesiod's compositions, poet's individuality comes to the fore quite forcefully: in the Theogony, Hesiod describes how he became a poet and in doing so, for the very first time in the European tradition, he claims a poem as his own under his own name. ${ }^{59}$ In the Word and Days, Hesiod then not only speaks about his life, but based on personal experiences also chooses a particular addressee from his surroundings, namely his own brother. ${ }^{60}$

57 This characteristic of constitution of archaic individuality is convincingly demonstrated in Vernant 1989.

58 Page 1962, fr. 1a, 47-48.

59 Hesiodus, Theogonia, 22.

60 From a different perspective, the individuality of a poet in Hesiod is also treated in Griffith 1983. Griffith shows that Hesiod's approach to authorship is not radically new: it is rooted in a much older epic tradition. At the same time, he also emphasises that the appearance of the author in first person is, in Hesiod's works, always motivated by a specific purpose and particular context. In other words, this self-relating is not a goal in itself. 
A poet as interpreter of musical words is therefore not quite transparent, he or she is not a mere loudspeaker whose existence ideally should not be even noticed. On the contrary: each poet interprets the divine voice in his or her own, unique way. ${ }^{61}$ In the function of an interpreter, a poet has a word to say in the poem and can claim his or her function proudly. And it is just possible that here, when speaking of poets who, while disclosing the nature of the world, left the shadows of anonymity and spoke about themselves, we are touching upon not only one of the sources of European reflexive thinking, but perhaps also one of the roots of the distinctly European sense of individuality. ${ }^{62}$

(Translated from Czech by Anna Pilátová)
Let us also add, that against this background, the traditional question of the extent to which Hesiod enters his creations as their individual author and to what extent this is a matter of a topos and self-stylisation, seems somewhat anachronistic. After all, if individuality is indeed constituted in appearing to others through musical speech, then literary (self-)stylisation does not conceal but co-creates the poet's 'true' individuality!

61 This issue is dealt with in Nancy 1982. According to Nancy, divine voice is accessible to a person only in the plurality of unique communications and this plurality is its essential feature. There are various ways in which poets interpret the divine voice and these differences are part of the nature of the divine voice as addressed to particular persons.
62 Publication of this text was made possible by the GA UK project No. 341715, Kosmos jako živá bytost $v$ antické filosofii [Cosmos as a Living Being in Ancient Greek Philosophy]. 


\section{REFERENCES}

Behr, C. A. (ed.) (1978). Aelius Aristides, Opera quae existant omnia, II. Leiden: Brill.

Behr, C. A. (1986). Publius Aelius Aristides, The Complete Works: Orationes I-XVI (trans. by C. A. Behr). Leiden: Brill.

Bonnafé, A. (1984). Poésie, nature et sacré, I: Homère, Hésiode et le sentiment grec de la nature, Lyon: Maison de l'Orient.

Burnet, J. (ed.) (1991-1992). Platonis Opera, I-V. Oxford; New York; Toronto: Clarendon Press.

Caldwell R. (transl.) (2015). Hesiod, Theogony $\mathcal{E}$ Works and Days, Indianapolis.

Chadwick, H. M., Chadwick, N. K. (1940). The Growth of Literature, III. Cambridge: Cambridge University Press.

Clay, J. S. (1988). "What the Muses sang: Theogony 1-115". Greek, Roman and Byzantine Studies 29, pp. 323-333.

Détienne, M. (1979). Les maîtres de vérité dans la Grèce archaïque. Paris: F. Maspero.

Diels, H. - Kranz, W. (eds.) (1996). Die Fragmente der Vorsokratiker: griechisch und deutsch. Zürich: Weidmann.

Dodds, E. R. (1951). The Greeks and the Irrational. Los Angeles.

Fischerová, S. (2006a). "Devět lhoucích Múz”. In: S. Fischerová, J. Starý (eds.), Puvod poezie: Proměny poetické inspirace $v$ evropských a mimoevropských kulturách, Praha: Argo, pp. 49-85.

Fischerová, S. (2006b). "Kosmos mých slov: Srovnání Hésiodovy ,Theogonie“ a Parmenidovy básně ,O přírodě“”. Filosofický časopis 54, pp. 331-361.

Griffith, M. (1983). "Personality in Hesiod". Classical Antiquity 2, pp. 37-65.

Janko, R. (1981). "The Structure of the Homeric Hymns: A Study in Genre". Hermes 109, pp. 9-24.

Kahn, C. (1994). Anaximander and The Origins of Greek Cosmology, Indianapolis; Cambridge: Hackett.

Long, H. S. (ed.) (1964). Diogenis Laertii vitae philosophorum, I-II. Oxford: Clarendon Press.

Luhanová, E. (2014). “Múzy a počátky reflexivity v archaickém řeckém myšlení”. Listy filologické 137(3-4), pp. 245-273.

Maehler, H. (ed.) (1975). Pindari Carmina cum fragmentis, Leipzig: Teubner.

Miller, A. M. (1986). From Delos to Delphi: A Literary Study of the Homeric Hymn to Apollo, Leiden: Brill.

Mühll, P. von der (ed.) (1993). Homeri Odyssea. Munich; Leipzig: Teubner.

Nancy, J.-L. (1982). Le Partage des voix. Paris: Galilée. 
Otto, W. F. (1955). Die Musen und der Göttliche Ursprung des Singens und Sagens. Düsseldorf: E. Diederich.

Otto, W. F. (1987). Essais sur le mythe. Mauvezin: Trans-Europ-Repress.

Page, D. L. (ed.) (1962). Poetae Melici Graeci. Oxford: Oxford University Press.

Pucci, P. (1977). Hesiod and the Language of Poetry. Baltimore: Johns Hopkins University Press.

Race, W. (1997). Pindar, Nemean Odes, Isthmian Odes, Fragments (ed., trans. by W. Race). Cambridge, Massachusetts: Harvard University Press.

Scodel, R. (2001). "Poetic Authority and Oral Tradition in Hesiod and Pindar". In: J. Watson (ed.), Speaking Volumes: Orality and Literacy in the Greek and Roman World, Leiden; Boston; Köln: Brill.

Šedina, M. (1995). “Krásná Gorgona”. In: L. Karfíková, A. Matoušek (eds.), Posvátný obraz a zobrazení posvátného, Praha: Česká křestanská akademie, pp. 13-38.

Šedina, M. (1997). Sparagmos. Praha: OIKOYMENH.

Sedley, D. (2010). "Hesiod's ,Theogony' and Plato's ,Timaeus'”. In: G. Boys-Stones, J. Haubold (eds.), Plato and Hesiod, Oxford: Oxford University Press.
Vandvik E. (1943). The Prometheus of Hesiod and Aeschylus (Skrifter utgitt av det Norske Videnskaps-Akademi i Oslo, II. Hist.-Filos. Klasse, 1942, No. 2), Oslo: Dybwad.

Vernant, J.-P. (1989). L'individu, la mort, l'amour: Soi-même et l'autre en Grèce ancienne. Paris: Gallimard.

Versnel, H. S. (1981). “Religious Mentality in Ancient Prayer". In: H. S. Versnel (ed.), Faith, Hope and Worship: Aspects of Religious Mentality in the Ancient World, Leiden: Brill, pp. 1-64.

Wendland, P. (ed.) (1897). Philonis Alexandrini Opera quae supersunt, II. Berlin: De Gruyter.

West, M. L. (ed.) (1966). Hesiod, Theogony. Oxford: Clarendon Press.

West, M. L. (ed.) (1978). Hesiod, Works and Days. Oxford: Clarendon Press.

West, M. L. (ed.) (1992). Iambi et Elegi Graeci, II. Oxford: Clarendon Press.

West, M. L. (ed.) (1998-2000). Homeri Ilias, I-II. Munich; Leipzig: Saur.

West, M. L. (ed. and transl.) (2003). Homeric hymns, Homeric apocrypha, Lives of Homer (ed., trans. by M. L. West). Cambridge; London: Harvard University Press. 